\title{
NMR Studies of Electrochemically Generated Germyl Anion
}

\author{
Tsuyoshi KUGITA* ${ }^{*}$, Mitsutoshi OKANO ${ }^{\dagger}$, Taketomo OHTSUKA ${ }^{\dagger}$ and Kunio MoCHIDA ${ }^{\dagger}$
}

Received June 15, 1994 ; Accepted August 10, 1994

\section{INTRODUCTION}

An organo-group 14 anion is one of the important species in the synthesis of the group 14 compounds 1 . We have recently shown that triphenylgermyl anion was produced by the electro-reduction of triphenylgermane in dinethylforamide, DMF, in the presence of tetrabutylammoniumtetrafluoroborate, TBATFB, as the electrolyte ${ }^{2)}$.

In this work, we attempted to produce methyldiphenylgermyl anion, $\mathrm{Ph}_{2} \mathrm{MeGe}^{-}$, and dimethylphenylgermyl anion, $\mathrm{PhMe}_{2} \mathrm{Ge}^{-}$, by electro-reduction of the corresponding germanes, and the effects of the number of the phenyl groups in the germyl anions are discussed based on the differences of ${ }^{13} \mathrm{C}$ NMR chemical shifts between these anions and germanes. Further, the differences between electrochemically generated germyl anions and germyl lithium compounds are also discussed.

\section{EXPERIMENTAL}

In a typical experiment, DMF containing 0.1 mol $\mathrm{dm}^{-3}$ methyldiphenylgermane, $\mathrm{Ph}_{2} \mathrm{MeGeH}$, and $0.3 \mathrm{~mol} \mathrm{dm}^{-3}$ TBATFB was used as an electrolyte solution. This solution was degassed three times and was transferred to a twocompartment electrolysis cell. Platinum wires were used as electrodes. Keeping the temperature between $230 \sim 235 \mathrm{~K}$, a constant current of $10 \mathrm{~mA}$ was supplied using a galvanostat. The electrolysis was carried out up to one Faraday per mole of $\mathrm{Ph}_{2} \mathrm{MeGeH}$ as the quantity of electricity was integrated using a coulomb meter. The yellow color of methyldiphenylgermyl anion was observed around the cathode with the progress of electro-reduction. To measure the NMR spectra, $0.6 \mathrm{~cm}^{3}$ of electrolyte solution was transferred into an NMR sample tube of $5 \mathrm{~mm}$ diameter under an argon atmosphere at $233 \mathrm{~K}$. The capillary inserted in NMR tube and sealed with a piece of paraffin

Department of Materials, Nishi-Tokyo University, (Uenoharamachi, Yamanashi 409-01, Japan) †Department of Photo-Optic Engineering, Tokyo Institute of Polytechnics, (Iiyama, Atsugishi, Kanagawa 243-02, Japan)

†DDepartment of Chemistry, Gakushuin University, (Mejiro, Toshimaku, Tokyo 171, Japan) Key Words: Electro-reduction, NMR Spectroscopy, Organogermyl Anion film. Immediately, the ${ }^{13} \mathrm{C}$ NMR measurement was done at $233 \mathrm{~K}$.

\section{RESULTS AND DISCUSSION}

The ${ }^{13} \mathrm{C}$ NMR spectra of the electrolyte solution of $\mathrm{Ph}_{2} \mathrm{MeGeH}$ before and after electrolysis are given in Fig. 1(a) and (b), respectively. Fig. 1(a) showed five peaks at 137.8 $134.9129 .1,129.8$ and $-5.6 \mathrm{ppm}$, which respectively were assigned as ipso, ortho, meta, para and methyl carbons in $\mathrm{Ph}_{2} \mathrm{MeGeH}$ in comparison to those in the literature ${ }^{3}$. In Fig. 1(b) these five peaks completely disappeared and new five peaks appeared at 168.6, 135.4, 126.5123 .2 and $6.4 \mathrm{ppm}$. Comparison of these data with those for methyldiphenylgermyl lithium, $\mathrm{Ph}_{2} \mathrm{MeGeLi}$, in $\mathrm{THF}^{3)}$, enabled us to attribute the five signals in Fig. 1(b) to those of methyldiphenylgermyl anion, $\mathrm{Ph}_{2} \mathrm{MeGe}-\mathrm{NBu}_{4}{ }^{+}$. These signals existed as long as the solution was kept at $233 \mathrm{~K}$ but disappeared at the temperature of the solution of $273 \mathrm{~K}$. The peaks appeared between 127 134 ppm in Fig.1(b) were probably due to the precursor, $\mathrm{Ph}_{2} \mathrm{MeGeH}$, and polygermane resulted from the decomposition of the germyl anions.

Electro-reduction of dimethylphenylgermane, $\mathrm{PhMe}_{2} \mathrm{GeH}$, and ${ }^{13} \mathrm{C}$ NMR measurement were also performed. In comparison its ${ }^{13} \mathrm{C}$ NMR spectrum with that of dimethylphenylgermyl lithium ${ }^{3}$, it was confirmed that the dimethylphenylgermyl anion, $\mathrm{PhMe}_{2} \mathrm{Ge}^{-} \mathrm{NBu}_{4}{ }^{+}$, was generated. These peaks disappeared at the temperature of $263 \mathrm{~K}$. This anion seems to be more unstable than $\mathrm{Ph}_{2} \mathrm{MeGe}^{-}$ $\mathrm{NBu}_{4}{ }^{+}$. When it is considered that triphenylgermyl anion, $\mathrm{Ph}_{3} \mathrm{Ge}^{-} \mathrm{NBu}_{4}{ }^{+}$, is stable at $273 \mathrm{~K}^{2}$, it is indicated that the thermal stability of these electrochemically generated germyl anions is decreased in the order of $\mathrm{Ph}_{3} \mathrm{Ge}^{-} \mathrm{NBu}_{4}{ }^{+}>$

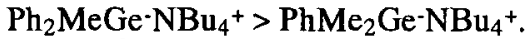

The ${ }^{13} \mathrm{C}$ NMR data for a series of germanes and germyl anions are summarized in Table 1 . It is apparent that the formation of germyl anions from neutral germanes causes the shifts of peaks for ipso and ortho carbons in the phenyl ring to a lower magnetic field and shifts of the peaks for para and meta carbons in that of a high magnetic field.

The differences in the ipso carbon shifts $\left(\Delta\left({ }^{13} \mathrm{C} i p s o\right)\right)$ for $\mathrm{Ph}_{3} \mathrm{Ge}^{-\mathrm{NBu}_{4}{ }^{+}}$vs. $\mathrm{Ph}_{3} \mathrm{GeH}$,

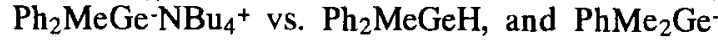
$\mathrm{NBu}_{4}{ }^{+}$vs. $\mathrm{PhMe}_{2} \mathrm{GeH}$ are 29.0, 30.8, and 34.6 
Table ${ }^{13} \mathrm{C}$ chemical shifts of germyl anions and corresponding germanes.

\begin{tabular}{|c|c|c|c|c|c|c|}
\hline \multirow[b]{2}{*}{ Species } & \multirow[b]{2}{*}{ Conditions } & \multicolumn{3}{|c|}{${ }^{13} \mathrm{C}$ chemical shifts } & \multirow[b]{2}{*}{ para } & \multirow[b]{2}{*}{$-\mathrm{Me}$} \\
\hline & & ipso & ortho & meta & & \\
\hline $\mathrm{Ph}_{3} \mathrm{GeH}^{\text {a) }}$ & DMF, 233K & 135.8 & 135.6 & 129.4 & 130.2 & \\
\hline $\mathrm{Ph}_{3} \mathrm{Ge}^{\left.-\mathrm{NBu}_{4}+\mathrm{a}\right)}$ & DMF, 233K & 164.8 & 137.0 & 126.8 & 123.8 & \\
\hline $\left.\mathrm{Ph}_{3} \mathrm{Ge}_{-} \mathrm{Li}^{+} \mathrm{b}\right)$ & THF, r.t. & 159.8 & 136.9 & 126.9 & 124.5 & \\
\hline Ph2MeGeH a) & $\mathrm{DMF}, 233 \mathrm{~K}$ & 137.8 & 134.9 & 129.1 & 129.8 & -5.6 \\
\hline $\mathrm{Ph}_{2} \mathrm{MeGe}^{\left.-\mathrm{NBu}_{4}+\mathrm{a}\right)}$ & DMF, 233K & 168.6 & 135.4 & 126.5 & 123.2 & 6.4 \\
\hline $\mathrm{Ph}_{2} \mathrm{MeGe}^{-} \mathrm{Li}^{+c} \mathrm{c}$ & THF, r.t. & 163.1 & 134.8 & 125.8 & 123.0 & 3.8 \\
\hline $\mathrm{PhMe} 2 \mathrm{GeH}^{\text {a) }}$ & DMF, 233K & 139.9 & 134.2 & 128.8 & 129.3 & -4.4 \\
\hline $\mathrm{PhMe}_{2} \mathrm{Ge}^{\left.-\mathrm{NBu}_{4}+\mathrm{a}\right)}$ & DMF, 233K & 174.5 & 134.6 & 126.3 & 122.2 & 9.3 \\
\hline $\left.\mathrm{PhMe}_{2} \mathrm{Ge}-\mathrm{Li}^{+} \mathrm{c}\right)$ & THF, r.t. & 167.4 & 133.5 & 125.3 & 122.0 & 5.4 \\
\hline
\end{tabular}

a) This work, DMF ( $\delta 36.1)$ used as reference. b) ref. 6 , cyclohexane $(\delta 27.2)$ used as reference.

c) ref. 3 , THF ( $\delta 25.2)$ used as reference.

ppm, while the differences in the para carbon shifts $\left(\Delta\left({ }^{13} \mathrm{Cpara}\right)\right)$ are $-6.4,-6.6$, and $-7.1 \mathrm{ppm}$, respectively. On the basis of the fact that the changes in chemical shifts provide a goon measure of charge density at this position ${ }^{4,5}$, it is confirmed that $\pi$ electrons in the phenyl rings of germyl anions are polarized in comparison with those of germanes. Further, the values of $\left(\triangle\left({ }^{13} \mathrm{C}\right.\right.$ ara $\left.)\right)$ are suggested that, as the number of phenyl rings attached to the germanium atom is reduced, the polarization of the phenyl ring is stronger. It can be explained that due to the increase of the number of the methyl group which is the electron donor, a larger charge built up on the germanium atom in the order of $\mathrm{PhMe}_{2} \mathrm{Ge}$ $\mathrm{NBu}_{4}{ }^{+}>\mathrm{Ph}_{2} \mathrm{MeGe}^{-} \mathrm{NBu}_{4}{ }^{+}>\mathrm{Ph}_{3} \mathrm{Ge}^{-} \mathrm{NBu}_{4}{ }^{+}$.

Buncel and co-workers performed the NMR measurements of several lithium and potassium 14 group anions in THF and confirmed that there were significant downfield shifts in ipso carbons shift was measured from triphenylgermyllithium to

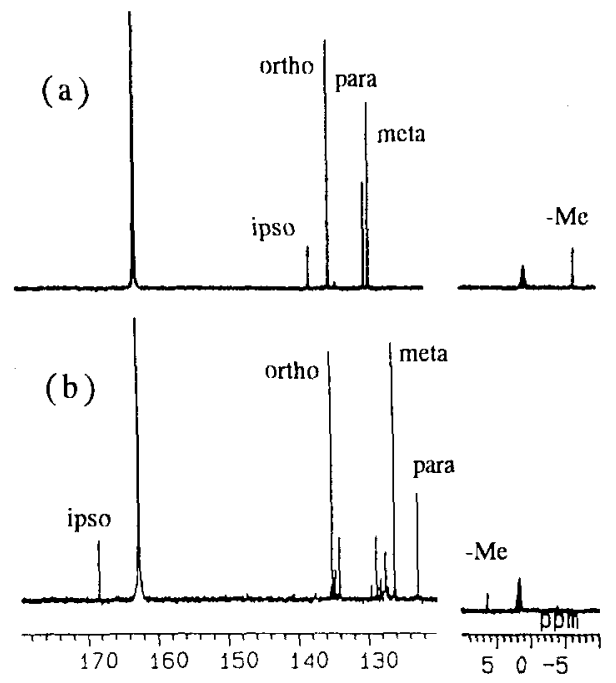

Fig. ${ }^{13} \mathrm{C}$ NMR spectra of the electrolyte solution of methyldiphenylgermane in DMF (a) before electrolysis and (b) after electrolysis. potassium. These results indicated that the interaction of Si-Li was stronger than that of Si-K, and this conclusion could probably be applied to the explanation for the NMR data of germyl anions. In this work, it is clear that the chemical shift of ipso carbon of $\mathrm{Ph}_{3} \mathrm{Ge}^{-} \mathrm{NBu}_{4}{ }^{+}$in $\mathrm{DMF}$ is and upfield shifts in para carbons from lithium salt to potassium salt ${ }^{6)}$. Especially, a large downfield lower not only than that of $\mathrm{Ph}_{3} \mathrm{Ge}^{-} \mathrm{Li}^{+}$in THF but also lower than that of $\mathrm{Ph}_{3} \mathrm{Ge}-\mathrm{K}^{+}$in THF. These results suggest that the interaction of $\mathrm{Ge}-\mathrm{NBu}_{4}$ is weaker than that of $\mathrm{Ge}-\mathrm{K}$, because of strong solvation to the $\mathrm{NBu}_{4}$ cation by DMF solution. Therefore, the obtained germyl anions with ammonium cations may have a reactivity different from those of the corresponding germyl anions with lithium counter cations, since they have different ${ }^{13} \mathrm{C}$ NMR chemical shifts. Studies concerning the reactivity will appear elsewhere.

This work was supported by a Grant-in-Aid for Scientific Research (No. 236) for M.O. (No. 06226280 ) from The Japanese Ministry of Education, Science and Culture.

\section{REFERENCES}

1) G. Wilkinson, F. G. A. Stone and E.W. Abel, "Comprehensive Organometallic Chemistry", Vol. 2, Pergamon, p. 468 (1982).

2)M. Okano, T. Kugita and K. Mochida, $J$. Electroanal. Chem., 356, 303 (1993).

3) M. Wakasa, Ph. D. Thesis, Gakushuin University, Tokyo, 1989.

4) G. A. Olah and R. J. Hundai, J. Am. Chem. Soc., 102, 6989 (1980).

5) E. Buncel, T. K. Venkatachalam, B. Eliasson and U. Edlund, J. Am. Chem. Soc., 107,303 (1985).

6) E. Buncel, T. K. Venkatachalam, U. Edlund and B. Eliasson, J. Chem. Soc. Commun., $1984,1476$. 